\title{
PENDEKATAN GOOD GOVERNANCE DALAM MEMPERKUAT KEAMANAN PERBATASAN NEGARA: STUDI DI WILAYAH LAUT NATUNA UTARA
}

\author{
Rio Yusri Maulana, dan Moh. Arief Rakhman \\ Fakultas Ilmu Sosial dan Ilmu Politik, Universitas Jambi, Jambi, Indonesia. \\ Email: rioyusrimaulana@unja.ac.id;moh.ariefrakhman@unja.ac.id
}

\begin{abstract}
ABSTRAK. Laut Natuna Utara adalah wilayah lama bernama baru yang di berikan Indonesia kepada salah satu wilayah laut yang berbatasan dengan Laut China Selatan. Setelah terdapat klaim sepihak terhadap perairan ini dari Republik Rakyat Tiongkok (RRT) pemerintah Indonesia kemudian memperkuat kekuatan militer di Natuna. Langkah ini memiliki resiko tersendiri baik bagi Indonesia maupun kawasan, sehingga pemerintah Indonesia perlu melakukan upaya penguatan di sektor politik. Rumusan masalah penelitian ini adalah bagaimana pendekatan politik keamanan dapat berperan dalam menjaga kedaulatan di Laut Natuna Utara?. Penelitian ini menggunakan metode deskriptif analitis dengan menggunakan teori national interest dan konsep good governance untuk memunculkan penjelasan bagaimana perimbangan kebijakan antara soft approach dan hard approach yang dilakukan pemerintah Indonesia dalam mengelola konflik di Natuna. Penelitian ini melihat bahwa kedulatan Indonesia sangat ditentukan oleh kepentingan nasional yang dihadirkan dalam kerangka konflik yang terjadi di Laut China Selatan. Dalam upaya menjaga keamanan wilayah Laut Natuna Utara, negara kemudian kemudian melakukan pendekatan politik dari aspek kekuatan militer (hard power) dan non-militer (soft power).
\end{abstract}

Kata kunci: Kepentingan Nasional; Kedaulatan; Pemerintah Daerah; Laut Natuna Utara.

\section{GOOD GOVERNANCE'S APPROACH TO STRENGTHENING STATE BORDER SECURITY: A STUDY IN THE NORTH NATUNA SEA.}

\begin{abstract}
The North Natuna Sea is a new name that Indonesia has given to one of the sea areas bordering the South China Sea. After there was a unilateral claim on these waters from the Chinese People's Republic of China (PRC), the Indonesian government then strengthen military forces in Natuna. This step has brought the risks in the region so that the Indonesian government needs to make efforts to strengthen the public sector. The formulation of the research problem is to describe how the security politics approach play a role in maintaining sovereignty in the North Natuna Sea? This study uses descriptive analytical methods using the theory of national interest and the concept of good governance to bring up an explanation of how the policy balance between the soft approach and the hard approach taken by the Indonesian government in managing conflict in Natuna. This research sees that the Indonesian sovereignty is very much determined by the national interests presented in the framework of the conflict in the South China Sea. In an effort to maintain the security of the North Natuna Sea region, the state then adopted a political approach from the aspect of military power (hard power) and nonmilitary power (soft power).
\end{abstract}

Keywords: National Interest; Sovereignty; Local Government; North Natuna Sea.

\section{PENDAHULUAN}

Wilayah nasional suatu negara merupakan modal dasar yang harus bisa di manfaatkan dengan maksimal untuk kepentingan peningkatan kesejahteraan dan keamanan bangsa. Klaim terhadap suatu wilayah negara oleh negara lainnya atau sering memunculkan pertentangan yang berujung pada memburuknya hubungan antar negara yang saling mengajukan klaim tersebut bahkan berpotensi membesar melibatkan banyak aktor negara lain di dalamnya. yang ikut terlibat dalam masalah tersebut. Konflik Laut Cina Selatan (LCS) adalah salah satu persengketaan pelik di wilayah Pasifik yang sampai sekarang masih belum bisa dituntaskan karena saling silang kepentingan banyak negara dengan masing-masing kepentingan nasionalnya dan berujung pada klaim wilayah.

Letak geografis Laut China Selatan (LCS) di antara beberapa negara yang mengklaim seperti Cina, Taiwan serta beberapa negara ASEAN seperti Filipina, Vietnam, Malaysia, Brunei Darusalam dan juga Indonesia mempunyai persamaan. Permasalahan dari wilayah ini adalah permasalahan tentang hak kepemilikannya, di mana RRT mengeluarkan historical evidence yang kemudian dikenal di dunia Internasional 
dengan peta nine-dashed line. Hal ini kemudian memancing beberapa negara lain untuk ikut juga mengeluarkan berbagai bukti yang mereka miliki mengenai status kepemilikan wilayah Laut China Selatan sebagai penguat untuk menandingi klaim sepihak yang dimiliki Cina. Dari sinilah salah satu penyebab koetegangan di Kawasan LCS dimulai (Pedrozo, 2014). Wilayah ini diduga memiliki sumber daya alam dan merupakan jalur perdagangan serta lalu lintas laut yang besar. Pada awalnya Indonesia tidak terlibat atau melibatkan diri secara langsung dalam silang sengketa di LCS. Namun, dengan bukti dan klaim yang dikeluarkan RRT, dengan memunculkan klaim bahwa wilayah laut di sebelah utara Kepulauan Natuna adalah bagian dari nine-dashed line (Scott, 2009) yang artinya masih bagian dari kepemilikan pihak Cina. Hal ini tidak hanya dialami oleh Indonesia saja, beberapa negara yang berada di wilayah Asia Tenggara juga mengalami hal yang kurang lebih sama. Hal ini kemudian mengakibatkan Mau tidak mau akhirnya konflik LCS ini memberikan dampak terhadap stabilitas politik dan keamanan di Asia Tenggara.

Sengketa Laut China Selatan yang sudah berlangsung sejak 1974 masih belum menemukan Solusi di 2019 (scmp.com, 2019). Klaim sepihak RRT semakin meningkatkan ancaman atas keamanan dunia. Titik sengketa Laut China Selatan adalah Kepulauan Spratly. Sengketa atas kepemilikan Kepulauan Spratly dan Kepulauan Paracel memiliki sejarahnya tersendiri karena berbatasan dengan wilayah perairan dari beberapa negara seperti Filipina, Vietnam, Indonesia dan Malaysia. Kepulauan ini terletak kurang lebih $1.100 \mathrm{~km}$ dari pelabuhan di Pulau Hainan, RRT dan $500 \mathrm{~km}$ dari pantai Kalimantan utara, Indonesia.

Sengketa di Laut China Selatan bisa mengarah pada sengketa dengan RRT, seperti halnya Vietnam dan Filipina yang sudah melibatkan penggunaan kekuatan militer. Meskipun dalam skala kecil hal yang sama kemungkinan besar bisa juga terjadi kepada Indonesia karena sengketa langsung akan terjadi apabila RRT memaksakan ingin menguasai wilayah Laut China Selatan sesuai yang diklaimnya akan mencakup wilayah laut Kepulauan Natuna Provinsi Kepulauan Riau. Jika ini yang terjadi maka ada dua aspek ketahanan nasional Indonesia yang terganggu, yakni aspek geografi dan aspek sumber kekayaan alam.
Pada 12 Juli 2016, Pengadilan Tetap Arbitrase (Permanent Court of Arbitration/PCA) memenangkan gugatan Filipina atas Cina di Laut Cina Selatan. Hal ini dianggap akan menguntungkan Indonesia apabila muncul sengketa perbatasan dengan RRT, meskipun secara resmi RRT juga menolak putusan Mahkamah Arbitrase Internasional ini dalam kasus yang diajukan Filipina. Beijing mengutip catatan-catatan sejarah untuk mendukung klaimnya, putusan itu akan menjadi sumber hukum internasional atas klaim historis RRT atas wilayah perairan Indonesia di kawasan Natuna (bbc.com, 2016).

Di Wilayah Natuna tercatat sebanyak tujuh pulau seperti Pulau Sekatung, Pulau Sengiun, Pulau Subi Kecil, Pulau Sepala, Pulau Sematan, dan pulau Tukong. Pulau-pulau tersebut hingga tahun 2014 belum berpenghuni, sehingga rawan melemahkan posisi Indonesia. Namun, per-airan Natuna merupakan salah satu daerah tujuan pariwisata di Indonesia bagi para pecinta snorkeling dan diving. Penduduk setempat banyak menggantungkan hidupnya sebagai nelayan dari laut ini.

Laut Natuna berbeda dengan perairan lainnya yang berada di wilayah Indonesia. Laut ini mengandung sumber daya yang berlimpah seperti kekayaan ikan yang berlimpah, kandungan minyak, dan gas alam. Salah satu jenis ikan langka yaitu Ikan Napoleon banyak ditemukan di perairan ini. Karena letaknya yang berada di wilayah perbatasan, potensi perikanan yang melimpah di Laut Natuna sering dicuri oleh kapal-kapal asing. Natuna adalah batas teritori yang patut diwaspadai dan dijaga ketat karena tempatnya yang sangat strategis bagi jalur lintasan militer Laut Cina Selatan. Bahkan, RRT telah membangun pangkalan militernya demi bisa menjangkau kawasan perairan Natuna.

Adanya berbagai macam fungsi strategis di wilayah Natuna memunculkan konsekuensi sehingga perlu pola pengelolaan wilayah secara khusus. Sampai dengan tahun 2017 Kabupaten Natuna telah memiliki 16 Kecamatan yang 6 diantaranya merupakan kecamatan pemekaran baru, diantaranya adalah Kecamatan Pulau Tiga, Bunguran Timur Laut, Bunguran Tengah, Siantan Selatan, Siantan Timur, dan Jemaja Timur dengan total jumlah sebanyak 75 kelurahan/desa.

Sebelah utara Kabupaten Natuna mempunyai perbatasan internasional dan 
nasional, yakni Vietnam dan Kamboja. Di selatan berbatasan dengan Sumatera Selatan dan Jambi, di bagian barat dengan Singapura, Malaysia, Riau, dan di bagian timur dengan Malaysia Timur dan Kalimantan Barat. Dengan kondisi geografis ini, Kabupaten Natuna wilayah lautnya menjadi kawasan pelayaran internasional wilayah laut ini juga adalah wilayah yang kaya dengan sumber daya alam laut dan sumber daya energi yang terkandung di dalamnya (Perkasa, 2016).

Walaupun RRT dan Indonesia selalu menyatakan tidak ada masalah perbatasan perairan, tetapi insiden penangkapan kapalkapal nelayan RRT oleh TNI pada Bulan Maret tahun 2016 di perairan Kepulauan Natuna membuktikan masalah itu nyata. Dalam kasus dimana RRT mengklaim perairan Natuna sebagai wilayah tradisional penangkapan ikan mereka. Sebuah sikap yang jelas-jelas ditolak oleh Indonesia dengan mengedepankan klaim Zona Ekonomi Eksklusifnya (ZEE). Langkah Penguatan lanjutan dilakukan oleh Indonesia adalah setahun setelah penolakan resmi Cina terhadapa keputusan Pengadilan Arbitrase Permanen adalah dengan langkah mengganti nama wilayah maritim di bagian barat daya Laut Cina Selatan menjadi "Laut Natuna Utara" perubahan ini resmi dilakukan pada 2017, Perubahan nama wilayah ini dilakukan berdasarkan temuan dari Pengadilan Arbitrase Permanen di Den Haag, Belanda pada 2016 mengenai perselisihan Laut Cina Selatan antara China dan Filipina. Pengadilan menyimpulkan, tidak ada dasar hukum atau historis atas klaim China terhadap perairan Laut Cina Selatan yang kaya sumber daya alam itu. Pemerintah membantah melakukan perubahan nama Laut Cina Selatan. Dalih yang dipakai, perubahan nama hanya bisa terjadi di wilayah Indonesia. Hal ini malah semakin menegaskan posisi Natuna dan Indonesia, bahkan Luhut Pandjaitan membantah bahwa pemerintah Indonesia mengganti penamaan Laut Cina Selatan dengan Laut Natuna Utara (kompas.com,17/07/2017).

Menurut Menteri Koordinator Bidang Kemaritiman itu pemutakhiran nama dalam peta hanya terjadi di wilayah Indonesia. Dalam hal ini menurut hukum Internasional, Indonesia memiliki kewenangan untuk memberikan nama wilayah di wilayah teritorialnya. Adapun untuk kepentingan pencatatan resmi secara internasional dilakukan melalui forum khusus pencatatan nama laut, yakni Organisasi Hidrografi Internasional. Dalam hal ini, organ TNI AL, yaitu Pusat Hidrografi-Oseanografi menjadi anggota forum dunia itu.

Perubahan nama menjadi Laut Natuna Utara sekaligus memperbaharui peta wilayah Indonesia yang belum diperbaharui sejak 2005. Pertimbangan lainnya mengenai Perubahan dan penyempurnaan ini dilakukan pemerintah yang didasarkan pada perkembangan hukum internasional yang berlaku dan adanya penetapan batas wilayah dengan negara tetangga. Pemerintah Indonesia dan Singapura pada 2016 telah menyepakati dan menandatangani batasbatas yang pasti antara kedua negara. Ada juga penyederhanaan perbatasan di Selat Malaka yang dilakukan untuk memberi ruang pada hukum internasional terkait kejahatan di wilayah jalur perdagangan padat itu.

Terlepas dari silang sengketa perubahan nama wilayah laut Natuna Utara, Pemerintah Indonesia berorientasi untuk menyatakan kedaulatannya. Hal ini akan menjadi instrumen pengirim pesan yang jelas, baik bagi warga Indonesia maupun secara diplomatis terhadap pihak-pihak yang terlibat silang sengketa di sekitar wilayah ini. Langkah yang dinilai tepat untuk membentengi kedaulatan dan menegakkan kewibawaan Indonesia dalam berinteraksi dengan negara-negara tetangga terdekat. Langkah-langkah lanjutan dalam bidang militer seperti pembangunan kapal selam dan mobilisasi kekuatan tiga matra ke Natuna semakin memperkuat posisi tawar Indonesia di perairan tersebut. Kebijakan pemerintah yang menginginkan agar Indonesia menjadi Poros maritim membutuhkan titik awalan, dan untuk ini kawasan Natuna Utara dianggap sebagai Kawasan potensial untuk disebut sebagai "poros maritim dunia". Dengan program-program penguatan wilayah terluar dan strategis seperti yang sedang berlangsung di Kepulauan Natuna.

Di samping upaya-upaya militer, aspek pembangunan daerah dan sektor pelayanan publik merupakan aspek penting untuk di optimalkan kawasan strategis kepulauan Natuna. Tidak optimalnya pengelolaan perbatasan oleh pemerintah Indonesia memberikan citra negatif yang sampai saat ini masih sering muncul dan menimbulkan kekhawatiran lain tentang kepulauan natuna sebagai objek sengketa. 
Kabupaten Natuna, Provinsi Kepulauan Riau merupakan salah satu wilayah perbatasan yang kurang lebih sama seperti daerahdaerah perbatasan lainnya, juga mengalami beberapa masalah yang berkaitan dengan letak geografisnya sebagai sebuah daerah terluar, antara lainnya yaitu (Juan, 2018):

1. Kabupaten Natuna Mempunyai wilayah dengan bentang yang cukup luas.

2. Pengelolaan potensi sumber daya alam oleh negara maupun swasta masih kurang maksmial terutama potensi sumber daya yang ada di laut.

3. Perbatasan belum ditangani secara maksimal dan masih bersifat sektoral.

4. Pendidikan dan kesejahteraan masyarakat masih rendah jika terutama dibandingkan dengan masyarakat di negara tetangga terdekat seperti Singapura.

5. Sarana dan prasarana pertahanan dan keamanan masih dinilai minim, dan ini menyebabkan lemahnya pengawasan terhadap pelanggaran batas negara. Masalah ini berangsur-angsur mendapat perhatian Pemerintah Pusat sehubungan dengan potensi konflik dan beberapa kejadian yang terjadi di seputaran laut Natuna Utara.

6. Program dan kegiatan pengembangan kawasan perbatasan belum terpadu.

7. Upaya promosi potensi pembangunan di pulau-pulau kecil yang minim.

8. Peralatan, frekuensi dan tenaga keamanan di laut masih terbatas.

9. Pasokan listrik belum memadai.

Berbagai permasalahan yang muncul di atas memerlukan pendekatan yang lebih bersifat soft dan non-militer (2005:4), kehadiran pemerintah dalam berbagai aspek diwilayah ini dinilai sudah sangat mendesak. Dalam rangka menjaga keutuhan wilayah negara, serta meningkatkan kesejahteraan masyarakat di wilayah ini, maka perlu pengelolaan yang dilakukan dengan memperhatikan keterpaduan pembangunan di bidang-bidang yang bersifat basic need pendidikan, sosial, ekonomi, budaya, hukum, sumber daya manusia dan keamanan.

Presiden menetapkan 5 pilar pembangunan Natuna, 1) kelautan dan perikanan, 2) Parawisata, 3) Migas, 4) Lingkungan Hidup, dan 5) Pertahanan. Posisi Natuna jika dilihat dari sudut keamanan memiliki tingkat ancaman besar.
Karenanya, memperkuat pertahanan di Natuna sesungguhnya adalah bentuk menyatakan sikap bahwa Indonesia adalah pemilik teritori Natuna yang sah dan tidak dapat terbantahkan. Untuk itu, pemerintah Indonesia sangat gencar mendukung ketahanan dan kedaulatan batas teritori wilayah perairan laut Natuna melalui pengerahan Angkatan Laut dan Angkatan Udara.

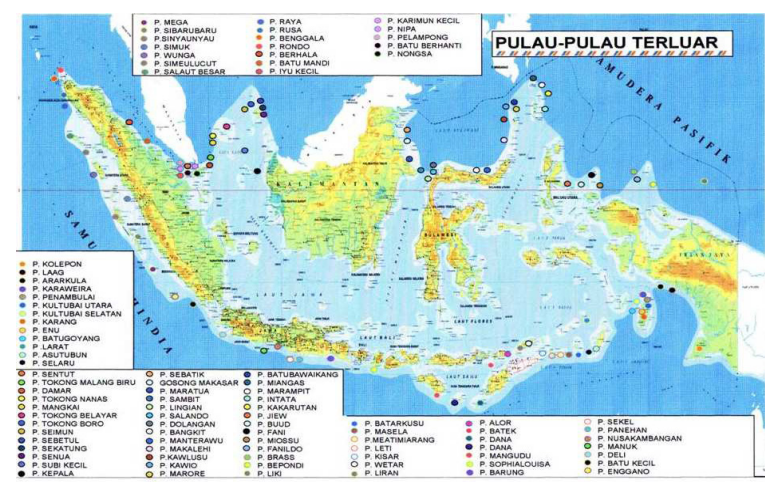

Sumber: Direktorat Jenderal Pengelolaan Ruang Laut, Kementerian Kelautan dan Perikanan

\section{Gambar 1. Peta Sebaran Pulau-pulau terluar Indonesia}

Banyaknya pulau terluar di Indonesia sering menimbulkan permasalahan diantara negara tetangga yang berdekatan dengan pulau itu. Sehingga pemerintah Indonesia perlu membuat suatu perencaan sistem keamanan nasional yang baik, sesuai dengan bentuk dan ancaman saat ini. Sistem keamanan ini sangat diperlukan terutama dalam menjaga kedaulatan dan keutuhan bangsa sehingga konflik claim sepihak dan kejadian seperti pulau Sipadan-Ligitan tidak terulang kembali. Apa yang bisa pemerintah Indonesia di Natuna dengan tidak hanya memperkuat pertahanan dari aspek militernya saja namun juga hal-hal yang bersifat non-militer. Upaya ini mampu menjadi proyek percontohan yang nantinya bisa diterapakan di berbagai wilayah perbatasan Indonesia khususnya daerah kepualaun dalam rangka menjaga kedaulatan negara dan akomodasi terhadap berbagai kepentingan nasional.

Konflik kedaulatan yang terjadi di Laut Natuna Utara dilihat oleh Deni (2017) yang menyimpulkan bahwa konflik yang terjadi di perairan laut natuna disebabkan oleh pengakuan China yang tetap memasukkan Zona Ekonomi Ekslusif (ZEE) Indonesia di Natuna ke dalam Peta Sembilan Garis Putus-putus (nine dash line) di Laut China Selatan. Upaya diplomasi yang dilakukan Indonesia terhadap klaim China 
atas ZEE Indonesia di Natuna adalah diplomasi preventif, hal ini menyebabkan terganggunya stabilitas kawasan sebab wilayah Laut China Selatan sendiri merupakan wilayah laut yang sangat luas yang secara geografis berdekatan dengan beberapa negara anggota ASEAN. Jika sampai terjadi konflik bersenjata, akan dapat memicu instabilitas di kawasan sebab Laut China Selatan diklaim pula oleh Malaysia, Vietnam, Filipina, dan Brunei Darussalam. Selain itu, Laut China Selatan merupakan jalur laut internasional yang banyak dilintasi oleh kapal-kapal dagang internasional. Maka ketegasan pemerintah Indonesia dalam hubungan diplomatik perlu dilakukan secara terukur dengan memperhatikan beberapa faktor lain, seperti ekonomi karena bagaimanapun Indonesia dan China merupakan mitra dagang yang terjalin baik sejak lama.

Sedangkan dalam penelitian yang dilakukan oleh Budiana dkk. (2019) yang melihat konflik Laut Cina Selatan (SCS) dari meningkatnya ancaman konflik yang terjadi di wilayah tersebut, maka dalam upaya untuk mengurangi konflik di SCS, pemerintah Indonesia terutama menggunakan soft power dan diplomasi. Namun, juga dipandang penting bagi Indonesia untuk meningkatkan sumber daya hard power, yang diyakini bahwa menggunakan kekuatan militer secara maksimal akan membawa dampak positif bagi Indonesia dalam menangani konflik Laut Cina Selatan.

Nadiah Oryza Shabrina (2017) menyampaikan dalam penelitiannya bahwa Indonesia tidak terlibat secara langsung dalam konflik yang terjadi, namun dampak konflik terhadap kestabilan keamanan kawasan serta ancaman terhadap kedaulatan Indonesia di kawasan Kepulauan Natuna memaksa Indonesia untuk melakukan langkah preventif demi menjaga kepentingan dan keamanan nasional Indonesia, Pemerintah Indonesia dalam dua kepemimpinan presiden terakhir mengalami perubahan respon, hal ini disebabkan oleh tiga hal, yang pertama adanya pernyataan juru bicara Kementrian Luar Negeri Tiongkok yang menyatakan bahwa wilayah Indonesia dan Tiongkok mengalami overlapping di perairan Natuna, Tiongkok beranggapan bahwa perairan Natuna merupakan traditional fishing zone Tiongkok. Kedua, tindakan provokatif nelayan-nelayan Tiongkok yang sengaja menangkapikan di perairan Natuna, yang diback-up oleh penjaga pantai Tiongkok
(CCG), maka Indonesia sudah seharusnya bersikap lebih tegas terhadap nelayan-nelayan tersebut. Dan ketiga adalah, Tiongkok yang tidak mengakui dan menolak keputusan PCA yang memenangkan Filipina dalam persengketaan di Laut Tiongkok Selatan (LTS), sehingga Indonesia dituntut untuk bersikap waspada akan tindakan Tiongkok yang tidak terduga-duga.

Maka dengan memperhatikan beberapa literatur diatas, dalam penelitian ini penulis menitikberatkanpadaanalisisyangmemunculkan perimbangan kebijakan antara soft approach dengan pendekatan good governance dan hard approach yang dilakukan pemerintah Indonesia dalam mengelola konflik di Natuna. Penelitian ini melihat bahwa kedulatan Indonesia sangat ditentukan oleh kepentingan nasional yang dihadirkan dalam kerangka konflik yang terjadi di Laut China Selatan. Dalam upaya menjaga keamanan wilayah Laut Natuna Utara, negara kemudian kemudian melakukan pendekatan politik dari aspek kekuatan militer (hard power) dan non-militer (soft power).

\section{Menjaga Kedaulatan Politik Indonesia dengan Memperkuat National Interest di Kawasan Perbatasan Negara.}

Kesungguhan Pemerintah Indonesia dalam menjaga kedaulatan dapat diperloeh dengan melihat konflik di kawasan natuna utara ini secara utuh, penulis berpandangan permasalahan kedaulatan yang terjadi di perairan Natuna Utara dapat di analisis menggunakan konsep Kepentingan nasional (national interest), suatu konsep yang dipakai dalam analisa bagaimana satu negara berinteraksi dengan negara lainnya. National Interest merupakan salah satu konsep yang sering dijadikan instrumen pembanding atau kriteria pokok bagi para elite pembuat kebijakan (decision makers) setiap negara sebelum sapai kepada pengambilan keputusan untuk kemudian memunculkan kebijakan atau atau aksi nyata. Pada praktiknya setiap fase dan keputusan yang merupakan kebijakan luar negeri (foreign policy) selalu diambil berdasarkan apa yang penting untuk kepentingan nasional. Hal itu baik langsung maupun tidak langsung diambil untuk mendukung target capaian nasional dan melindungi kepentingan nasional.

DonaldE.Nuchterlain(1979:57) mengemukakan kepentingan negara sebagai kebutuhan yang dirasakan oleh suatu negara dalam hubungannya 
dengan negara lain yang merupakan lingkungan eksternalnya. Dalam konflik di kawasan Laut Cina Selatan berbagai macam kepentingan negaranegara yang terlibat memunculkan kerumitan tersendiri sehingga menghambat solusi.

Dalam sengketa yang terjadi di Laut Cina Selatan atau wilayah yang disebut juga sebagai Laut Natuna Utara, setiap negara yang terlibat mempunyai landasan kebijakan politik luar negeri yang berbeda satu dengan lainnya. Kebijakan yang di landasakan pada kepentingan nasionalnya masing-masing saling berkontestasi melibatkan segala macam sumber daya yang dipunyai oleh masing-masing negara terkait. Bagaimanapun apa yang menjadi kebijakan sebuah negara dalam bertidak di ranah internasional dalam konsep national interest akan selalu berdasarkan dari apa yang menjadi cerminan prioritas kepentingan dalam negerinya atau kepentingan nasionalnya.

Dalam kasus konflik laut Cina Selatan, Indonesia pada awalnya tidak terganggu karena tidaktermasukdalamnegarayangikutmengklaim wilayah di perairan. Kepentingan Indonesia di wilayah ini kemudian mulai terganggu oleh klaim sepihak RRT yang mengeluarkan peta "U" atau dikenal dengan Nine Dash Line yang dikeluarkan oleh RRT pada tahun 1993. Negara ini memasukan perairan Natuna kedalam peta klaimnya. Hal ini memunculkan dampak melebar, sehingga bukan hanya terfokus kepada pulau Spratly dan Paracel saja, namun berimbas pada Zona Ekonomi Eksklusif (ZEE) yang dimiliki Indonesia. Dengan terganggunya wilayah utara kepulauan Natuna dalam sengketa Laut Cina Selatan jelas berdampak terhadap stabilitas keamanan dan ekonomi Indonesia. Sebab, Indonesia memiliki kepentingan nasional strategis di wilayah ini, seperti proyek eksplorasi pertambangan minyak dan gas bumi di kawasan ZEE Natuna. Apalagi dengan arah kebijakan maritim baru yang merupakan fokus strategis dibawah pemerintahan Jokowi (2014-8), upaya RRT mengklaim perairan Natuna dianggap mengganggu kepentingan nasional Indonesia.

Menurut Morgenthau (1954:8), kepentingan nasional merupakan alat untuk mengejar kekuasaan, karena melalui kekuasaan itulah suatu negara dapat mengontrol negara lain. Lebih spesifiknya konsep kepentingan nasional adalah kemampuan negara untuk melindungi dan mempertahankan identitas fisik, politik, dan kultur dari gangguan negara lain. Felix E. Oppenheimer (1992:57) menekankan tujuan kesejahteraan pemerintahan nasional dalam level internasional. Hal tersebut mengindikasikan bahwa kepentingan nasional dari suatu negara adalah untuk menjaga otonomi politik dan integrasi nasionalnya demi keberlangsungan kesejahteraan masyarakatnya sampai ke tahap internasional. Secara garis besar kepentingan nasional adalah tujuan, cita-cita dan harapan yang ingin dicapai oleh suatu negara. Donald E. Nuchterlain (1979:57) membaginya kedalam 4 fokus:

1. Defense Interest: Kepentingan untuk melindungi Negara atau rakyat dari ancaman fisik dari Negara lain atau perlindungan ancaman terhadap system suatu Negara.

2. Economic Interest: Kepentingan ekonomi yang berupa tambahan nilai secara ekonomi dalam hubungannya dengan Negara lain dimana hubungan perdagangan yang dilakukan dengan Negara lain akan mem-berikan keuntungan.

3. World Order Interest: Kepentingan tata dunia dengan adanya jaminan pemeliharaan terhadap sistem politik dan ekonomi internasional dimana suatu Negara dapat merasakan keamanan sehingga rakyat dan badan usahanya dapat beroperasi diluar batas Negara dengan aman.

4. Ideological Interest: Kepentingan ideologi dengan perlindungan terhadap serangkaian nilai-nilai tertentu yang dapat dipercaya dan dapat dipegang masyarakat dari suatu Negara yang berdaulat.

Perjuangan kepentingan nasional di bidang keamanan terkait dengan menjaga keutuhan wilayahnya salah satunya dengan menggunakan sarana diplomasi. Untuk mendukung keberhasilan diplomasi tentu saja harus didukung elemen kekuatan sebuah negara atau yang dalam tulisan ini disebut sebagai hard approach. Untuk mengkaji mengenai kebijakan pemerintah Indonesia dalam pengelolaan wilayah perbatasan di laut natuna utara, maka tulisan ini juga akan merujuk kepada apa yang dipaparkan oleh Paul R. Viotti dan Mark V. Kauppi (2013:185-189) bahwa dalam memutuskan sebuah kebijakan faktor kepentingan saja adalah tidak cukup. Tetapi harus mendapatkan dukungan dengan hadirnya target capaian khusus atau objektivitas. 
Pengaruh dari kepentingan nasional akan memainkan faktor penting bagaimana negara memunculkan berbagai kebijakan dalam situasi konflik di kawasan, hal ini menjadi fokus perhatian dengan menimbang natuna sebagai pusat ekonomi baru di wilayah perbatasan dan ini adalah salah satu upaya dalam mendukung 5 pilar pengembangan yang di tetapkan oleh presiden berdasarkan Nawacita. Ekonomi yang baik akan menarik pertumbuhan jumlah penduduk di wilayah perbatasan, yang di Indonesia termasuk salah satu permasalahan.

Gerry E. Hendershot dalam tulisannya Population Size, Military Power and Antinatal Policy (1973:517-524) Personel militer diambil dari kelompok usia tertentu. Negara dengan jumlah penduduk besar akan dengan mudah mendapatkan calon angkatan militer dibandingkan negara berpopulasi kecil. Jumlah penduduk dimasukkan sebagai salah satu indikator utama kekuatan militer. Penduduk bisa ditempatkan sebagai tentara atau pekerja untuk industri militer seperti pembuatan peluru, bom, seragam dan peralatan khusus militer. Strategi ini sudah diterapkan Cina, India dan Amerika Serikat. Senada dengan pendapat Hendershot, Penelitian yang dilakukan Oleh LIPI, terdapat enam faktor yang mempengaruhi pertahanan nasional. Adapun faktor yang mempengaruhi pertahanan yaitu: (1) anggaran pertahanan; (2) jumlah penduduk suatu negara; (3) ancaman konvensional dan non konvensional; (4) anggaran pertahanan negara lain;(5)kemampuan keuangan pemerintah; (6) harga alutsista; dan (7) jumlah personil sistem pertahanan. Bagaimana pentingnya jumlah populasi dengan strattegi pertahanan negara juga kembali ditegaskan dalam buku putih kemenhan 2015. Jumlah populasi masuk kedalam komponen pendukung bagi pertahanan nasional, sehingga pemerataan jumlah penduduk terutama ke wilayahwilayah batas terluar seperti kepulauan Natuna menjadi penting. setelah ekonomi dan populasi pengelolaan pemerintahan yang baik adalah hal selanjutnya yang harus bisa dilakukan oleh pemerintah pusat maupun daerah.

\section{Relevansi Pendekatan Good Governance} sebagai Refleksi Komitmen Politik Lokal.

Dalam memetakan persoalan di Natuna Utara ini, Penulis melihat bahwa komitmen pemerintah pusat maupun pemerintah daerah di uji dengan tidak hanya meletakkan landasan penyelesaian masalah pada pendekatan militer, namun juga pada aspek tata kelola pemerintahan lokal yang yang memperkuat pembangunan ekonomi masyarakat dengan menggunakan konsep good governance atau pembenahan ke dalam pemerintahan sendiri (soft approach).

Tingkat kesejahteraan yang baik pada masyarakat di wilayah berpotensi konflik adalah modal utama pemerintah untuk memperkuat keamanan wilayah. Keamanan wilayah tidak akan mungkin bisa diwujudkan jika masyarakat yang tinggal di wilayah perbatasan dalam tingkat kesejahteraan yang rendah. Pemerintah perlu hadir dalam pemenuhan kebutuhan hidup yang layak, pelayanan publik yang berkualitas, dan sarana prasarana yang memadai. Dengan demikian, akan muncul kesadaran rakyat dan penguatan identitas kebangsaan untuk menjaga keutuhan kedaulatan wilayah negara. Pendekatan ini melihat fungsi perbatasan sebagai pembangunan wilayah dan kesejahteraan masyarakat sekaligus keamanan negara.

Melalui good governance pemerintah mendukung pelaksanaan kebijakan pembangunan kesejahteraan rakyat. Pendekatan ini juga meniscayakan tersedianya dana, aparatur pemerintah yang profesional dan amanah serta pelibatan aktor non negara termasuk masyarakat baik pada level tinggi, menengah maupun rendah. Dengan begitu, sebagian permasalahan yang menjadi kekhawatiran terhadap perkembangan potensi konflik yang hadir akan terminimalisasi. Khusunya apabila penyebaran konflik menyasar wilyah natuna maka pemerintah daerah dan masyarakat telah memiliki sebuah pengelolaan daerah yang baik. Taschrereau dan Campos dalam Thoha (2003:63) menyebutkan bahwa tata kelola pemerintahan yang baik atau good governance merupakan suatu kondisi yang menekankan pada kesamaan, sinergi, kesejajaran, dan keseimbangan peran serta memungkinkannya saling kontrol antara pemerintahan (government), masyarakat sipil (civil society), dan swasta (private).

Berdasarkan Undang-Undang Nomor 23 Tahun 2014 tentang Pemerintahan Daerah, kewenangan pemerintah daerah kabupaten sangat terbatas, bahkan tidak sama sekali jika dilihat dari prespektif keamanan dan pertahanan, sehinga Pemerintah Kabupaten Natuna tidak dapat berbuat banyak untuk menjaga dan 
mengelola wilayah perairan natuna. Maka sinergitas antara pemerintah pusat, provinsi, dan kabupaten menjadi penting dalam mengelola konflik dalam sebuah kawasan, dengan memastikan tata kelola daerah yang baik, maka komitmen politik lokal sangat diperlukan. Menurut OECD (Organization for Economic Cooperation Development) good governance dengan penyelenggaraan manajemen pembangunan yang solid dan bertanggung jawab sejalan dengan demokrasi dan pasar yang efisien. Penghindaran salah alokasi dana investasi adalah langkah pencegahan korupsi, baik secara politik maupun administratif. Menurut United Nation Development Program (UNDP) dalam Dwiyanto (2008:80), good governance memiliki 8 (delapan) karakteristik utama, yaitu:

1. Participation, setiap warga negara mempunyai suara dalam pembuatan keputusan, baik secara langsung maupun melalui intermediasi institusi legitimasi yang mewakili kepentingannya

2. Rule of Law, kerangka hukum harus adil dan dilaksanakan tanpa pandang bulu terutama hukum untuk hak asasi manusia;

3. Transparency, dibangun atas dasar kebebasan arus informasi;

4. Resposiveness, setiap lembaga dan proses penyelenggaraan pemerintahan dan pembangunan harus mencoba melayani setiap stakeholders;

5. Consensus Oriented, good governance menjadi perantara kepentingan yang berbeda untuk memperoleh pilihan terbaik bagi kepentingan yang lebih luas, baik dalam hal kebijakan kebijakan maupun prosedur;

6. Equity, semua warga negara mempunyai kesempatan untuk meningkatkan atau menjaga kesejahteraan mereka;

7. Effectiveness and efficiency, proses-proses dan lembaga lembaga menghasilkan produknya sesuai dengan yang telah digariskan, dengan menggunakan sumber-sumber yang tersedia sebaik mungkin;

8. Accountability. para pembuat keputusan dalam pemerintahan, sektor swasta dan masyarakat (civil society) bertanggung jawab kepada publik dan lembaga-lembaga stakeholders.

Prinsip-Prinsip di atas berkorelasi pada perwujudan pemerintahan yang bersih (clean government). Good Governance adalah suatu sasaran yang akan diwujudkan dalam pelaksanaan asas-asas umum pemerintahan yang layak sebagai norma mengikat yang menuntun pemerintah dalam mewujudkan good governance. Sinergi antara good governance dengan desain national interest berkontribusi terhadap dan pemerintahan yang berwibawa, menjaga wilayah terluar Indonesia tanpa melepas perhatian terhadap pengembangan daerah.

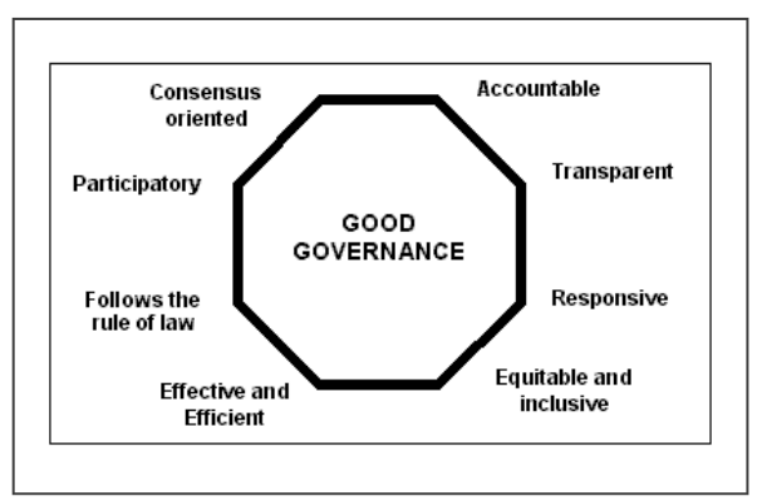

sumber : www.unescap.org/pdd

\section{Gambar 2. Karakteristik Good Governance METODE}

Metode yang digunakan dalam penelitian ini adalah metode deskriptif analitis: Metode deskripsi analisis menurut Sugiyono (2009:29) adalah metode yang menggambarkan suatu peristiwa atau masalah menjadi topik kajian secara sistematik dan mengandalkan analisa terhadap peristiwa-peristiwa tersebut dari sudut sebab-akibat. Dalam metode ini dipelajari masalah-masalah yang berlaku dalam hubungan internasional termasuk dalam hubungan, kegiatan, sikap, pandangan, serta proses yang sedang berlangsung yang dikaitkan dengan aspek good governance sebagai pilihan solusi terhadap permasalahan yang sedang berlangsung di kawasan Natuna. Selain itu, tulisan ini menggunakan kajian pustaka dalam rangka membuat prediksi serta mendapatkan makna dan implikasi dari masalah pengaruh konflik Laut China Selatan terhadap stabilitas keamanan di kepulauan Natuna.

\section{HASIL DAN PEMBAHASAN}

\section{Dampak Sengketa Laut Natuna Utara terhadap Kedaulatan Politik Indonesia}

Pemerintah Indonesia melalui Kementerian Koordinator Bidang Maritim pada 14 Juli 2017 secara resmi mengeluarkan peta Republik 
Indonesia yang baru, yang menekankan bahwa Zona Ekonomi Eksklusif (ZEE) Natuna telah diberi nama "Laut Natuna Utara" (Sinaga, 2017). Wilayah tersebut merupakan bagian dari Laut China Selatan yang sebagian sebagian berada di dalam wilayah yang diklaim sebagai milik Cina. Secara diplomatis, pemerintah Indonesia beralasan bahwa pemberian nama baru terhadap wilayah tersebut dilakukan karena dua alasan: pertama, untuk mencegah kebingungan di antara pihak-pihak yang ingin mengeksploitasi landas kontinen tersebut, mengingat wilayah itu adalah teritori kedaulatan Indonesia; dan kedua, untuk memberikan petunjuk yang jelas kepada Tim Penegakan Hukum di Angkatan Laut Indonesia. Pro dan kontra seputar peristiwa ini menandai babak baru posisi Indonesia dalam Konflik silang sengketa di Kawasan Laut Cina Selatan.

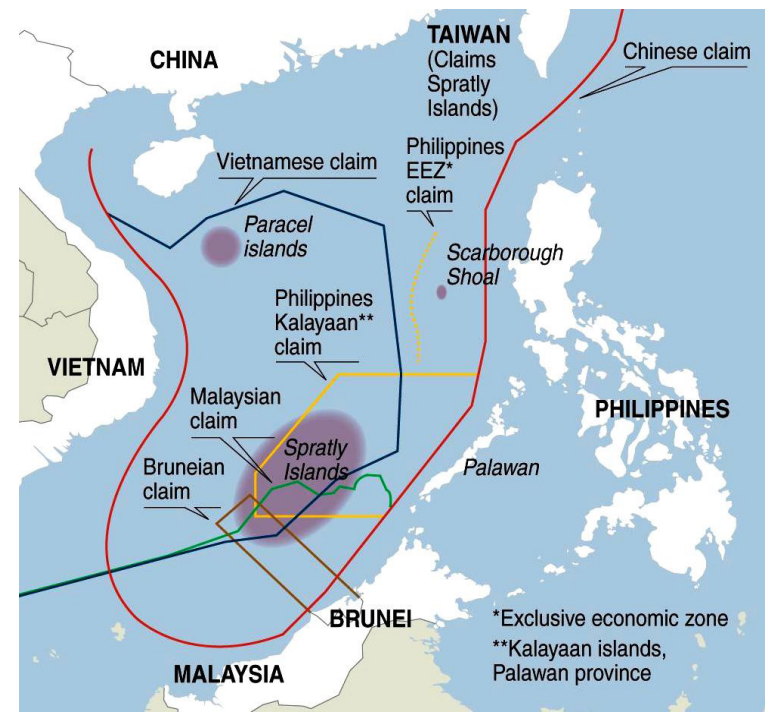

(sumber: southchinasea.org)

Gambar 3. Wilayah garis putus-putus yang menjadi claim Cina

Posisi Indonesia yang memberikan penegasan masalah persengketaan di Kawasan laut RRT selatan, sehingga membuat posisi Indonesia kembali di perhitungkan. Dengan kebijakan luar negeri asertif pemerintah pusat memunculkan kesan yang berbeda dibandingkan dari kebijakan pemerintahan sebelumnya. Presiden Jokowi mengunjungi Natuna yang secara politis dilakukan untuk memberikan tanda kepada pemimpin Tiongkok di Beijing bahwa Indonesia tidak akan diam dan berjuang melindungi hak-hak kedaulatannya baik dengan pendekatan soft approach maupun hard approach.

Para analis Nasional maupun Internasional yang mengkritik tindakan RRT di Laut Cina
Selatan memberikan apresiasi terhadap apa yang dilakukan Indonesia. Strategi yang menandai dikeraskannya pendekatan Indonesia dalam hubungannya dengan RRT. Langkah yang menegaskan sebagai negara yang menjadi titik tumpu dua samudra, Indonesia menyatakan retorikanya yang tegas tentang kedaulatan dan hak-hak kelautannya.

Pendekatan pemerintah Indonesia terkait Laut Cina Selatan di bawah kepemimpinan Presiden Joko Widodo terlihat fokus dalam memperkuat kedaulatan Indonesia termasuk memperkuat kehadiran Indonesia di Kepulauan yang berbatasan dengan Laut Cina Selatan. Pembangunan pangkalan perang dan pengerahan angkatan laut di sekitar perairan itu merupakan hal nyata bagaimana kebijakan Joko Widodo terhadap polemik masalah Laut Cina Selatan.

Langkah di atas bukan tanpa resiko, ada resiko lain yang akan dihadapi oleh Indonesia dengan kebijakan yang di uraikan di atas, Aaron L. Connelly (2016) dalam tulisannya bahwa strategi Pemerintah Indonesia tersebut sesungguhnya dapat melemahkan negaranegara tetangga yang mempunyai kepentingan di hadapan RRT. Hal ini akan membuat negaranegara tetangga Indonesia yang sebetulnya mempunyai potensi kekuatan secara kolektif dalam kerangka Organisasi Internasional bernama ASEAN. Nantinya akan sulit mencapai kesatuan dalam menyikapi sengketa Laut Cina Selatan serta tak memiliki kekuatan penuh untuk menghadap konfrontasi Cina di Laut Cina Selatan, yang memang cukup berbeda dengan era kepemimpinan Indonesia sebelum pemerintahan Presiden Jokowi. Pada saat itu Indonesia sering menjadi "motor" bagi negara ASEAN yang berkonflik di Kawasan ini. Tanpa adanya kesatuan yang kuat dari anggota ASEAN, kekuatan besar seperti Amerika Serikat akan terundang hadir dan mengambil posisi sebagai "pemandu" bagi ASEAN guna menghadang tindakan-tindakan yang dilakukan oleh RRT di Laut Cina Selatan.

Padahal hadirnya kekuatan besar di wilayah Asia Tenggara itu akan memengaruhi kestabilan kawasan yang secara tak langsung sesungguhnya juga akan berpengaruh di Kepulauan Natuna sebagai wilayah Indonesia. Namun, terlepas dari kekhawatiran itu, pemberian nama Laut Natuna Utara sebagai pesan yang kuat dari Indonesia kepada RRT agar tak sembarangan soal batas 
wilayah menyusul berbagai insiden yang pernah terjadi.

Perubahan nama Perairan Natuna mungkin sedikitmenggangguRRT ditunjukandengan respon resmi dari pemerintah RRT. Namun nampaknya dengan berbagai langkah yang Nampak dilakukan oleh RRT dalam menyikapi berbagai macam kebijakan pemerintah Indonesia terkait Kawasan Natuna Utara, termasuk konsolidasi kekuatan militer Indonesia di kawasan ini yang secara masif dilakukan dan mulai operasional sejak 2016. Beberapa di antaranya pendirian pangkalan militer terpadu, mobilisasi 2000 personil militer ke wilayah ini, beberapa kali latihan perang di wilayah Natuna, kemunculan bandara militer yang juga sekaligus bandara sipil, dan dibentuknya satuan TNI Terintegrasi, dimasukannya Kabupaten Natuna dalam masterplan percepatan danperluasan pembangunan.

Pemerintah RRT sampai pada tahun 2019 ini terkesan menahan diri, dan menunjukan usaha untuk memahami bahwa hal tersebut tidak akan mengubah status quo. Nampaknya Beijing juga memahami bahwa perubahan nama tersebut adalah bentuk nasionalisme domestik Indonesia, yang secara strategis sangat penting bagi pemerintahan Jokowi.

Kemungkinan hadirnya kekuatan besar lain selain RRT di wilayah ini akan memengaruhi kestabilan kawasan yang secara tak langsung sesungguhnya juga akan berpengaruh di Kepulauan Natuna sebagai wilayah Indonesia. Dalam tingkatan lebih ekstrem ada kemungkinan memunculkan poros-poros baru interaksi internasional dikawasan ini. Poros ini terbentuk akibat realitas terkini yang memunculkan citra bahwa ASEAN sebagai organisasi menjadi kurang kreatif dalam isu ini. Bahkan dengan manuver Indonesia, RRT dinilai telah berhasil berhasil "membuka ikatan antar negara ASEAN" dan meminggirkan peran organisasi negara-negara di Asia Tenggara ini sebagai sebuah organisasi internasional dalam tata kelola keamanan regional. Hal ini nantinya bisa jadi memicu kemunculan poros yang di dorong oleh kepentingan nasional masing-masing negara yang terlibat persengketaan. Selain RRT kekuatan besar lain yg disinyalir akan ambil bagian adalah Amerika serikat.

Kemunculan poros-poros baru di konflik Laut Cina Selatan berpotensi memunculkan kembali berbagai dampak baik langsung maupun tidak terhadap kedaulatan Indonesia, seperti terjadinya arm race antarnegara yang berkepentingan di Laut Cina Selatan. Arm race terjadi karena kepentingan nasional sebuah negara dalam aspek politis yang kuat, sehingga persediaan alusita memang menjadi syarat utama (Glaser, 2000: 257) dan sejarah membuktikan bahwa arm race ini akan membawa suatu kondisi menuju ke arah yang buruk, yakni perang.

Terlepas dari bagaimana pemerintahan presiden Jokowi mengelola konflik Laut Cina Selatan, di Natuna Utara, Indonesia Sebagai primus inter pares di ASEAN mempunyai tanggung jawab moral untuk melakukan penyatuan persfektif dan mengembalikan peran penting organisasi ASEAN dalam kasus ini. Oleh karena itu strategi yang berbasiskan pendekatan militer yang dilakukan oleh Indonesia tidak bisa dijalankan sebagai satu-stunya strategi utama. hard approach yang digunakan harus sedikit diturunkan demi kepentingan bersama yang lebih effektif dan berguna bukan hanya bagi Indonesia namun juga bagi kawasan.

\section{Komitemen Politik sebagai Soft Approach dalam Menyeimbangkan Kedudukan Stra- tegis Pemerintahan Lokal di Natuna.}

Kabupaten Natuna adalah wilayah terluar Indonesia yang termasuk dalam wilayah perbatasan negara dan secara administratif berada di bawah Provinsi Kepulauan Riau. Konsep kawasan perbatasan negara adalah salah satu pintu masuk kedalam teritori Negara Kesatuan Republik Indonesia yang pengelolaannya dilakukan secara lebih komprehensif dengan mengutamakan pendekatan kesejahteraan yang ditopang dengan pendekatan keamanan.

Perkembangan yang terjadi tidak terlepas dari kesiapan Indonesia terhadap perubahan sistem pemerintahan dari sentralistik menjadi desentralistik seperti sekarang ini. Fungsi strategis sebagai kawasan perbatasan negara secara langsung menempatkan Wilayah Natuna sebagai bagian penting dari NKRI. Sebagai akibatnya, peranan pemerintah pusat di wilayah mempunyai ruang yang cukup strategis karena menyangkut keamanan dan keselamatan negara. Namun perubahan ini diperkirakan akan meningkatkan intensitas konflik antar pusat dan daerah, daerah dengan negara-negara yang berbatasan teritori, jika tidak diantisipasi maka akan berdampak pada kualitas kedaulatan Indonesia. 
Terkait dengan hal itu kesamaan visi, distribusi informasi dan diseminasi kebijakan termasuk tahapan rencana yang telah disusun dalam rangka mencapai kesepakatan antar stakeholder dalam konteks peningkatan kapasitas daerah yang dibutuhkan dalam pelaksanaan pengembangan wilayah dan pembangunan daerah terutama di kepulauan Natuna. Pada perkembangan lebih lanjut, pembangunan di kepulauan Natuna terbentur beberapa permasalahan dalam tingkat nasional, regional dan lokal.

Kepentingan nasional hadir tidak terlepas hanya pada dukungan keamanan (defence interst) dalam memproteksi warga negara, namun kehadiran pemerintahan yang menjamin keberlangsungan tata kelola wilayah yang baik dapat dilakukan dengan pendekatan good governance. Hal ini yang di maksud penyeimbang dengan soft approach. Beberapa isu yang muncul di atas dapat diselesaikan pada level pemerintah daerah. Ketimpangan kewenangan yang hadir akibat perubahan paradigma dengan menghadirkan sebuah tata kelola pemerintahan daerah yang berpegang teguh pada prinsip pelayanan yang baik, proteksi terhadap kebutuhan dasar, dan menghadirkan kolaborasi antar level pemerintahan yang didukung oleh mapannya regulasi.

Maka dalam menopang kepentingan nasional (national interest) di perlukan inisiatif daerah dsebagai garda terdepan yang akan berhadapan dengan potensi konflik ini hari demi hari (day by day dilema). Pemerintah pusat telah membuka jalan dengan terbitnya Peraturan Pemerintah Nomor 38 Tahun 2017 tentang Inovasi Daerah hadir menjadi dasar legal framework dalam implementasi inovasi daerah, di mana perangkat daerah yang membidangi penelitian dan pengembangan diamanatkan untuk menjadi pemacu dan pemicu pertumbuhan inovasi daerah. Hal ini adalah hanya salah satu dari peraturan yang bisa dioptimalkan di Natuna, dengan agenda percepatan pembangunan yang di peruntukan untuk Kabupaten Natuna terkait dengan letak geografisnya yang berada di wilayah terluar Indonesia. Selain kekuatan militer yang bisa di fokuskan untuk memberikan efek penggentar bagi negara yang bersinggungan langsung dengan wilayah perbatasan Indonesia, tata kelola pemerintahan yang baik pun bisa di maksimalkan dan menjadi suatu bentuk role model baru terkait dengan bagaimana kebijakan pemerintah di terapkan di daerah-daerah perbatasan dengan penguatan ekonomi daerah.

Isu mengenai Perbatasan Indonesia hingga saat ini masih memprihatinkan dari berbagai segi. Daerah-daerah perbatasan termasuk Natuna, persentase penduduk miskin dipengaruhi peningkatan garis kemiskinan dari pendapatan masyarakat masih sebesar $\mathrm{Rp}$ 253,491 per bulan pada tahun 2011, menjadi Rp 302.043 pada tahun 2016. Dengan angka ini maka pedapatan yang diperloeh hanya $\mathrm{Rp} 1,5$ juta per bulan atau pendapatan hanya Rp300 ribu per orang. Dengan demikian masih masuk pada kategori keluarga miskin. Kondisi ini memperlihatkan bahawa Natuna mengalami keterlambatan ekonomi yang berdampak terhadap kemiskinan (radarkepri.com, 2018) karena tiadanya program dan proyek pemerintah maupun swasta. Panjangnya garis perbatasan baik di daratan maupun lautan sangat sulit untuk diawasi dengan reguler oleh aparat keamanan. Akibatnya pelanggaran wilayah perbatasan (Kemitraan, 2011:40), penyelundupan, dan aktivitas ilegal lintas batas lainnya seringkali terjadi. Apa yang bisa dilakukan pemerintah Indonesia di Natuna Sejatinya membuka pintu perbaikan untuk masalah pengelolaan perbatasan secara lebih luas lagi.

Dengan pendekatan soft approachini, pemerintah daerah berperan besar terhadap kekuatan penyeimbang. Data memperlihatkan bahwa potensi yang belum dimaksimalkan di Natuna Utara dapat dilihat dari hasil kegiatan pertambangan di Kabupaten Natuna meliputi minyak mentah dan gas bumi. Sebagai penopang perekonomian utama produksi minyak mentah mengalami penurunan dari 5.652 .721 barel menjadi 4.773.443 barel pada tahun 2017 . Walaupun mengalami penurunan produksi terdapat kenaikan harga pertama setelah beberapa tahun mengalami penurunan. Dengan kenaikan harga dari 40,13 U\$ menjadi 49,49 U\$. Sama halnya dengan minyak mentah, gas bumi mengalami penurunan jumlah produksi sebesar 14 persen. Namun harga rata-rata gas bumi turun lebih besar yakni 50 persen pada tahun 2017 (BPS Kabupaten Natuna, 2018).

Potensi lain adalah sumber pendapatan dari pariwisata dan sektor pendukung lainnya bila dibandingkan dengan tahun 2016. Jumlah hotel/penginapan dikabupaten Natuna pada 
tahun 2017 mengalami penambahan. Jumlah hotel/penginapan pada tahun 2016 sebanyak 41 dan pada tahun 2017 sebanyak 44, artinya pendapatan daerah meningkat seiring dengan hadirnya wisatawan. Wisatawan di Kabupaten Natuna pada tahun 2017 terjadi peningkatan yang cukup tinggi baik wisatawan domestic maupun wisatawan mancanegara. Dari 9.412 wisman domestik tahun 2016 menjadi 10.313 wisatawan domestik di tahun 2017. Begitu juga halnya dengan wisatawan mancanegara dari 426 menjadi 538 wisman. (BPS Kabupaten Natuna, 2018).

Dari data di atas memperlihatkan banyak pengembangan kebijakan yang ditopang oleh potensi daerah, dengan sasaran memperkuat kedudukan masyarakat lokal dengan ekonomi yang mandiri, saat ini kondisi kesejahteraan di natuna belum menggambarkan perbaikan signifikan, data kemiskinan pada gambar dibawah ini meunjukan data penduduk miskin di natuna cenderung meningkat setiap tahunnya.

\begin{tabular}{|c|c|c|c|c|c|}
\hline $\begin{array}{c}\text { Kabupaten/Kota } \\
\text { Regency/Municipality }\end{array}$ & 2013 & 2014 & 2015 & 2016 & 2017 \\
\hline (1) & (2) & (3) & (4) & (5) & (6) \\
\hline \multicolumn{6}{|l|}{ Kabupaten/Regency } \\
\hline 1. Karimun & 14,81 & 15,38 & 14,82 & 15,03 & 16.94 \\
\hline 2. Bintan & 9,32 & 9,27 & 9,25 & 9,91 & 9.37 \\
\hline 3. Natuna & 2,75 & 3,05 & 3,23 & 3,25 & 3.53 \\
\hline 4. Lingga & 12,34 & 13,10 & 13,22 & 12,36 & 12.35 \\
\hline 5. Kepulauan Anambas & 1,77 & 1,97 & 2,65 & 2,75 & 2.84 \\
\hline \multicolumn{6}{|l|}{ Kota/Municipality } \\
\hline 1. Batam & 57,52 & 61,40 & 59,94 & 57,29 & 61.16 \\
\hline 2. Tanjungpinang & 20,57 & 20,00 & 19,30 & 19,82 & 19.19 \\
\hline Kepulauan Riau & 119,08 & 124,17 & 122,40 & 120,37 & 125.37 \\
\hline
\end{tabular}

(sumber: BPS Kabupaten Natuna, 2018)

Gambar 5. Jumlah Penduduk Miskin Menurut Kabupaten/Kota di Provinsi Kepulauan Riau (ribu), 2013-2017

Dari data di atas, perlu penguatan teta kelola pemerintahan daerah. Di sisi lain pendekatan good governance yang memfokuskan pada penguatan pemerintahan lokal dapat dianggap langkah tepat untuk menyeimbangkan kepentingan nasional dengan tetap menjaga kokohnya kedaulatan. Dengan mengelola pemerintahan daerah secara benar dan dengan penerapan inovasi serta penyadaran terhadap potensi daerah serta ancaman konflik pemerintah daerah dapat menghindari ekses negatif dalam tata kelola pemerintahan di daerah dan hal ini akan memperkuat kedudukan Indonesia dalam posisi konflik di Laut Cina Selatan.

\section{Menjaga Stabilitas Ekonomi Daerah sebagai Representasi Kepentingan Negara di Natuna}

Sebagai representai kepentingan negara di Natuna, besarnya potensi konflik yang hadir menyebabkan ketidakstabilan harga yang berdampak pada ketidakberdayaan pemerintah negara dan daerah terhadap penangkapan ikan oleh asing dan melakukan transaksi di Natuna. Data kementerian Kelautan dan perikanan pada tahun 2016 sebanyak 57 unit kapal ikan asing ditangkap di laut Natuna. (beritasatu.com, 2016)

Faktor ekonomi ini merupakan tidak terlepas dari perwujudan kepentingan nasional negara. Dengan mengelola ekonomi secara tepat, maka sebuah keuntungan untuk dapat bersaing dengan negara lain. Faktor ini memiliki pengaruh kuat terhadap product demands dan besaran biaya yang harus dimunculkan dalam rangka meningkatkan daya beli masyarakat.

Ketidakstabilanperekonomianmengakibatkan pasar belum mampu digerakan secara optimal, sehingga pusat-pusat transaksi masih terkendala ketersediaan dan arus barang. Hal ini menimbulkan dampak kepada pelaku usaha di Natuna dan memang kontribusinya selama ini masih belum mendongkrak perekonomian setempat. Keadaan perekonomian memberikan pengaruh terhadap pasar dan daya beli masyarakat. Masa berkembangnya ekonomi masyarakat yg belum optimal memunculkan dampak tuntutan terhadap keberadaan jasa dan barang yang melambat juga. Ditambah pasokan barang lebih banyak dari luar Indonesia dan dapat mengurangi rasa akseptabilitas terhadap kedaulatan Indonesia yang bukan sasaran kepentingan nasional.

Perlunya menjaga kepentingan ekonomi nasional di Natuna adalah suatu hal yang tidak bisa dikompromikan. Pemerintah harus secepatnya lebih dirasakan kehadirannya dalam perekonomian di Kabupaten Natuna terutama wilayah Laut Natuna Utara supaya bisa mengelola perairan tersebut Terutama dalam dua hal, yaitu perikanan dan migas.

Dalam sektor migas, potensi besar yang dipunyai kawasan ini adalah 16 blok migas dengan 5 blok sudah beroperasi dan 11 blok tengah tahap eksplorasi. Untuk wilayah cekungan Blok East Natuna saja ada beberapa blok yaitu South Natuna Sea Block B, East Natuna, Tuna, NE Natuna, North Sokang, East Sokang, South Sokang. Kemudian ada Sokang. Berdasarkan 
Data Komite Eksplorasi Nasional (KEN), total cadangan dari delapan wilayah kerja di cekungan Laut Natuna Utara terdiri dari penemuan gas yang sudah terbukti sebesar 47,2 triliun kaki kubik (TCF). Sementara cadangan minyak sebesar 318,39 juta tangki barel (MMSTB) (Anastasia, 2017)

Untuk bidang perikanan pemerintah pusat mendorong agar nelayan lebih optimal karena Laut Natuna Utara menyimpan potensi perikanan yang sangat besar. Wilayah kepulauan Natuna sejatinya diberkahi dengan berbagai sumber daya alam yang masih dikelola secara belum maksimal bahkan beberapa sektor sama sekali belum tersentuh (natunakab.go.id, 2019) berikut beberapa potensi yang dimiliki wilayah ini:

- Sumber daya perikanan laut yang mencapai lebih dari 1 juta ton per tahun dengan total pemanfaatan hanya $36 \%$, yang hanya sekitar 4,3\% dimanfaatkan oleh Kabupaten Natuna sendiri.

- Pertanian dan perkebunan seperti ubi-ubian, kelapa, karet, sawit dan cengkeh.

- Objek wisata: bahari (pantai, pulau selam), gunung, air terjun, gua dan budidaya.

- Potensi pertambangan gas. sektor D-Alpha yang terletak $225 \mathrm{~km}$ di sebelah utara Pulau Natuna (di ZEEI) dengan total cadangan 222 trillion cubic feet (TCT) dan gas hidrokarbon yang bisa didapat sebesar 46 TCT merupakan salah satu sumber terbesar di Asia.

\section{Struktur Politik dan Kontrol Terhadap Birokrasi}

Pengelolaan tata pemerintahan yang baik (good governance) merupakan kunci dalam penguatan dimensi Soft Approach di Kepulauan Natuna yang merupakan wilayah perbatasan negara dengan beragam tantangan yang ada, dengan mengukuhkan tata kelola pemerintahan melalui penguatan kelembagaan dan birokrasi yang mampu menjalankan kewenangannya secara tepat. Thoha (2003:63) menyebutkan bahwa good governance merujuk kondisi yang menekankan pada kesamaan, sinergi, kesejajaran, dan keseimbangan peran serta memungkinkannya saling kontrol antara masyarakat dan pemerintah, maka birokrasi sebagai wajah pemerintah daerah harus menjamin pelayanan yang baik bagi masyarakat.

Sehubungan dengan hal itu, maka penguatan kapasitas kelembagaan Pemerintah Daerah dalam pengembangan daerah perbatasan semakin penting dalam dinamika otonomi daerah dimana pemerintahdaerahdidoronguntukmeningkatkan kesejahteraan masyarakat, meningkatkan pelayanan umum, dan meningkatkan daya saing daerah. Dalam kerangka tersebut, diterapkan prinsip otonomi seluas-luasnya sehingga daerah diberikan kewenangan mengurus dan mengatur semua urusan pemerintahan berdasarkan ketentuan yang berlaku.

Persoalan penguatan peran kelembagaan dan birokrasi di wilayah Natuna memiliki kompleksitas yang khas sebagai wilayah perbatasan negara yang memerlukan perlakuan khusus didalam tata kelola pemerintahan, termasuk dalam peningkatan kualitas pelayanan publik. Hasil penelitian William Ramphele (2003) mengidentifikasi keterbatasan pengembangan kapasitas kelembagaan pemerintah daerah di Afrika Selatan, dipengarui oleh tidak memadainya infrastruktur dan penataan kelembagaan pemerintah yang sangat tergantung kepada anggaran, lemahnya dalam mengelola kapasitas birokrasi yang tersedia. Sebagian besar pemerintah daerah belum mampu membangun sistem dan proses dukungan internal pemerintah daerah secara memadai. Hal ini berdampak pada belum memadainya kinerja internal pemerintah daerah, dan kurangnya motivasi untuk membangun kapasitas pemerintah daerah.

Kondisi tersebut menjadi refleksi terhadap tatakelola pemerintahan di Natuna, meskipun saat ini akses kepada pelayanan masih menjadi pekerjaan rumah pemerintah daerah dengan tantangan geografis yang dinamis, hingga saat ini belum adanya penguatan birokrasi secara maksimal disebabkan pemerintah daerah melakukan pendekatan yang sama dengan daerah lain. Pemerintah daerah juga perlu memperhatikan perkembangan konflik yang akan muncul diakibatkan tergerusnya rasa kepemilikan daerah dengan infiltrasi pengaruh dari luar. Pemerintah harus siap dengan dengan perubahan sosial yang memberikan dampak kepada pertumbuhan daerah yang terjadi di Kabupaten Natuna bahwasannya Pemerintah Kabupaten Natuna dalam membuat suatu kebijakan kurang memperhatikan kondisi pelayanan, lingkungan sosial, tantangan asimetris, dan kemampuan ekonomi masyakarat yang berdampak kepada kemampuan masyarakat dalam bidang ekonomi yakni meroketnya harga sewa tempat sehingga 
terpengaruhnya harga barang yang dijual oleh pedagang sebagai pemilik usaha. Dampak dari munculnya harga tersebut membuat kemampuan ekonomi masyarakat menjadi menurun. Hal ini kemudian mempengaruhi kehidupan sosial masyarakat dalam memenuhi kebutuhan hidupnya. Faktor sosial mempengaruhi suatu perusahaan mencakup nilai, sikap, dan opini masyarakat.

\section{Intervensi sebagai Komitmen Politik}

Kepentingan nasional dengan hadirnya pendekatan secara militer di kepulauan Natuna perlu diimbangi dengan komitmen politik pada level lokal. Hadirnya pemerintah pusat dengan mengganti nama wilayah maritim di bagian barat daya Laut Cina Selatan menjadi "Laut Natuna Utara" merupakan keseriusan kepemimpinan pada level nasional. Sejalan dengan hal tersebut kepemimpinan di daerah harus memiliki pandangan strategis kedepan (strategic vision) pengembangan daerah berdasar pada proyeksi masa depan yang terukur, yakni dengan mempecepat pertumbuhan ekonomi daerah dengan membangun infrastruktur yang membuka keberlangsungan akses pada peningkatan potensi pariwisata, perikanan, energi, serta visi strategis kepemimpinan daerah dalam penguatan sumber daya manusia dalam menghadapi persaingan langsung dengan negara lain. Kepeimpinan yang baik adalah bentuk praksis agar atmosfer politik di Natuna tetap kondusif serta sadar akan tanggung jawab di masa yang akan datang dan potensi konflik yang akan muncul perlu menjadi perhatian bersama. Karena harus disadari bahwa penguasa wilayah secara sosiologis dan kultural adalah masyarakat Natuna yang terdampak langsung terhadap konflik Laut Cina Selatan.

\section{SIMPULAN}

Dari pembahasan di atas, maka kedulatan Indonesia sangat ditentukan oleh kepentingan nasional yang dihadirkan dalam kerangka konflik yang terjadi di Laut China Selatan. Untuk mewujudkan keamanan nasional secara menyeluruh merupakan tanggung jawab dari sebuah negara. Pemerintah Indonesia terus memperhatikan segala aspek yang berpotensi menjadi ancaman bagi stabilitas keamanan negara dengan memperhatikan kepentingan nasional, baik ancaman internal maupun eksternal.
Dalam mengatasi segala bentuk ancaman bagi Indonesia serta mendukung tercapainya keamanan nasional, negara kemudian kemudian melakukanpendekatanpolitikdariaspekkekuatan militer (hard power) dan non-militer (soft power). Potensi konflik terbuka juga diantisipasi dengan hard approach / power, di mana negara melakukan proteksi dengan mengedepankan upaya pertahanan dan keamanan, seperti dengan mempekuat kapabilitas militer. Upaya diplomasi damai dengan tetap mengambil posisi tengah dalam penyesaian perdamaian antar negara juga dilakukan negara. Di lain sisi proteksi negara dengan soft approach juga dilakukan dengan penguatan tata kelola pemerintahan pada level daerah khususnya Kabupaten Natuna sebagai wilayah terluar, seperti melalui peningkatan pelayanan, kesejahteraan, yang berujung pada kepatuhan masyarakat terhadap NKRI.

Dari penegasan di atas maka dapat dipahami bahwa wilayah perbatasan negara memiliki arti yang sangat strategis, baik secara teritorial maupun dilihat dari kepentingan negara. Oleh karena itu, pemerintah perlu memiliki komitmen yang kuat dan memberi perhatian yang serius terhadap upaya membangun dan merekonstruksi wilayah perbatasan, sekaligus memastikan terselenggaranya tata kelola pemerintahan yang baik. Dengan demikian, peningkatan derajat hidup masyarakat akan sejalan dengan kepentingan negara dalam menjaga kedaulatan. Secara sinergis, komitmen pemerintah ini hanya dapat berjalan jika didukung oleh masyarakat dan komitmen seluruh pemangku kepentingan yang ada di wilayah Laut Natuna.

\section{DAFTAR PUSTAKA}

bbc.com (16 Juli 2016) diakses dari https:// www.bbc.com/indonesia/berita indonesia/2016/07/160712_indonesia_laut_Cina_selatan di akses 20/02/2019

Beritasatu.com. (27 Juni 2016) Natuna Jadi Sentra Perikanan dan Kelautan Terpadu. Diakses dari https://www.beritasatu.com/ ekonomi/372012/natuna-jadi-sentraperikanan-dan-kelautan-terpadu

Budiana, M., Fedryansyah, M., Djuyandi, Y., \& Pancasilawan, R. (2019). Indonesia Military Power Under the Increasing Threat of Conflict in the South China Sea. 
Central European Journal of International \& Security Studies . 2019, Vol. 13 Issue 4, p259-274. 16p.

CNA Analysis \& Solution, Raul (Pete) Pedrozo "China versus Vietnam: An Analysis of the Competing Claims in the South China Sea"

Connelly, A.L. (2016) Indonesia in the South China Sea: Going it alone, https://www. lowyinstitute.org/public ations/indonesiasouth-china-sea going-it-alone.

Deni, F., Sahri, L. (2017). Upaya Diplomasi Indonesia Terhadap Klaim China Atas Zona Ekonomi Eksklusif Indonesia Di Laut Natuna. International \& Diplomacy Vol. 3, No. 1 (Juli-Desember 2017)

Dwiyanto, A. (2006). Reformasi Birokrasi Publik Indonesia. Yogyakarta : Pusat Studi Kependudukan dan Kebijakan Universitas Gajah Mada.

Erwin Kurnia, N.M. (2 Desember 2014) "Pengaruh Konfik Laut Cina Selatan Terhadap Sistem Pertahanan Negara Indonesia. Universitas Pertahanan Indonesia, Jakarta : 8 di unduh dari https:// www.academia.edu/7289711/Pengaruh Konflik_Laut_China_Selatan_Terhadap_ Sistem_Pertahanan_Negara

Fahmal, H.A.M. (2006) Peran Asas - Asas Umum Pemerintahan Yang Layak Dalam Mewujudkan Pemerintahan yang Bersih. Yogyakarta : UII Press.

Glaser, C. L., (2000). "The Causes and Consequences of Arms Race". Annual Review of Political Sciences, 3 (2000): 251-276.

Hendershot, G.E. (1973) Population Size, Military Power, and Antinatal Policy, diakses dari https://www.jstor.org/ stable/2060879

Hendrayady, A. (2018). Strategi Pembangunan Wilayah Perbatasan Provinsi Kepulauan Riau. Jurnal Ilmu Administrasi Negara (JUAN). (2018).Vol.6 No. 1.

Holsti, K.J. (1975). Politik Internasional: Suatu Kerangka Analisis. Terjemahan oleh Wawan Djuanda. 1992. Bandung: Binacipta. International Law. 1942. $8^{\text {th }}$ edn.
Kementrian Pertahanan Indonesia. (2015). Buku Putih Pertahanan Indonesia 2015. Diakses dari https://www.kemhan.go.id/ wp-content/uploads/2016/04/BPPIINDO-2015.pdf

Kemitraan. (2011). Partnership Policy Paper No. 2/2011 Kebijakan Pengelolaan Kawasan Perbatasan Indonesia.

kompas.com. (2 Agustus 2017) diakses dari https://internasional.kompas.com/ $\mathrm{read} / 2019 / 02 / 08 / 17110301 /$ halangiproyek-filipina-di-laut-china-selatanbeijing-disebut-kirim-95

Lembaga Administrasi Negara dan BPKP. (2007). Jakarta: LAN.

Mardiasmo. (2002). Akuntansi Sektor Publik. Yogyakarta : CV. Andi Offset.

Morgentau, H. J. (1954) Politics Among Nations: the Struggle For Power and Peace, $2^{\text {nd }}$ editions, New York: Alfred A. Knopf.

Natunakab.go.id. (20 Januari 2019) diakses dari https://natunakab.go.id/ekonomi-daerahdi-kabupaten-natuna/

Nucterlain, D. E. (1979). National Interest a New Approach, Orbis. Vol 23. No.1 (Spring)

Perkasa, A. (23 Juni 2016) Laut Natuna Utara jadi sumber Migas Asia,https://www. cnnindonesia.com/nasional/. Di akses 20/02/2019

Perwita, A.A.B., \& Yani, Y.M. (2005) Pengantar Ilmu Hubungan Internasional, Bandung: PT Remaja Rosdakarya.

Radarkepri.com. (4 September 2018). Diakses pada laman https://radarkepri. $\mathrm{com} / \mathrm{wabupa} 0 \mathrm{~m}$ as a lah-besarnatuna-kemiskinan-dan-lambatnyaperkembangan-perekonomian-di-daerah/

Ramphele, W. (2003) Discussion paper on Local Government Capacity Building, Department of Provincial and Local Government. South Africa Government. Dalam Discussion Paper On Local Government www.environment.gov.za/ HotIssues/2003jul24/

Scmp.com (29 Oktober 2018) diakses dari https://www.scmp.com/news/china/ diplomacy/article/2174342/china-has- 
built-new-structure-bombay-reef-southchina-sea-us.

Scott, S.V. (2016). China's nine-dash line, international law, and the Monroe Doctrine analogy, diakses dari https://journals.sagepub.com/ doi/10.1177/0920203X16665054

Shabrina, N. O. (2017). Perubahan Respon Indonesia Terhadap Klaim Nine-Dash Line Tiongkok yang Melewati Perairan Natuna. Jurnal Analisis Hubungan Internasional, Vol. 6 No. 2, Agustus 2017.

Sinaga, L.C., (10 November 2017) politik. lipi.go.id diakses pada http://www. politik.lipi.go.id/kolom/kolom-1/politikinternasional/1165-laut-natuna-utara-danrespon-tiongkok

Sugiyono. (2009). Metode Penelitian Kuantitatif, Kualitatif dan R\&D. Bandung: Afabeta.

Swastiwi, A.W. (2017). Perdagangan Dan Ekonomi Maritim Di Kepulauan Anambas Abad 19-20. Balai Pelestarian Nilai Budaya Kepulauan Riau. (Laporan Kajian).

Thoha, M. (2003). Birokrasi dan Politik Indonesia. Jakarta: Rajawali Pers.

Viotti, et. al, (2013). International Relations and World Politics Fifth Edition, Pearson Education, Inc. New York. 